\section{APPLICATION OF CARBAMIDE AS FOAMING AGENT OF FE-MN-C ALLOY FOR DEGRADABLE BIOMATERIAL CANDIDATE WITH POWDER METALLURGY PROCESS}

\author{
Yudha Pratesaa,b*, Bambang Suharnoa, Aufandra Cakra \\ Wardhana ${ }^{a}$, Sri Harjantoa
}

aDepartment of Metallurgy and Materials Engineering, Universitas Indonesia, 16024, Jakarta, Indonesia

bResearch Center for Biomedical Engineering, Universitas Indonesia, 16024, Jakarta, Indonesia
Article history

Received

19 March 2018

Received in revised form

10 September 2018

Accepted

1 October 2018

Published online

15 December 2018

*Corresponding author yudha@metal.ui.ac.id

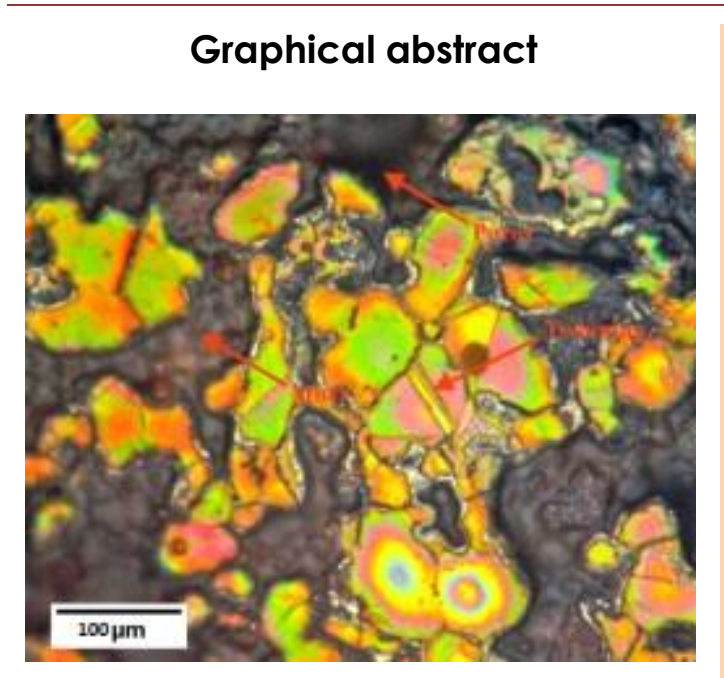

\begin{abstract}
The foam-structured metal has many advantages as a bone implants such as low density, lightweight and adequate surface roughness for cell attachment. An agent is often required to make porosity in the faam structured material, it called as a foaming agent. Carbonate powder usually uses because it can quickly decompose into a gas that forms a porosity. However, the final product is an irregular porosity which reduces the mechanical properties of materials. This study proposes carbamide as a foaming agent by the method of Sintering and Dissolution Process (SDP). This study was conducted by adding $5 \%$ and $10 \%$ weight percent of carbamide to $\mathrm{Fe}-35 \mathrm{Mn}-0,5 \mathrm{C}$ in an argon atmosphere in temperature $1100^{\circ} \mathrm{C}$. Addition more content of carbamide resulted in lowering density to $3.73 \mathrm{gr} / \mathrm{cm}^{3}$ and porosity about $52 \%$. It produces spherical porosity with size within the range of carbamide diameter $(1 \mathrm{~mm})$. Phases of $5 \%$ and $10 \%$ carbamide samples are Austenite, Ferrite, and $\mathrm{MnO}_{2}$. The carbamide is also completely removed from the final product which safe for the toxicity issue.

Keywords: Carbamide, Porosity, Powder Metallurgy
\end{abstract}

(C) 2019 Penerbit UTM Press. All rights reserved

\subsection{INTRODUCTION}

Application for the bone implant is metallic materials. From the industrial perspective, value of implant increase every year. In 2019, it will reach $\$ 33.000$ Million.

Metal-based biomaterials are commonly used as implants since a century ago. The first introduced implant is metal plates that used to repair broken bones in 1895 [1]. Now, Stainless Steel 316L is the most commonly used alloy for the implant. It offered good economist value, inert with the body and had excellent mechanical properties. Nowadays, implant research is continuing by improving the inert of metal in body, surface modification by a coating method to improve the nature of bioactivity [2], until the development of biomaterials that can be decomposed (biodegradable material) naturally [35].

The degradable biomaterial is an advanced biomaterial. This material will degrade by itself in the body for a period, and it is expected that the degradation product is not harmful to the body. Previous studies used magnesium alloys for degradable biomaterials, especially for orthopedic applications. Magnesium proved its absorbable to the body because it is an element that plays a role in the growth of bones and blood [6]. Magnesium has a 
density that similar to natural bone $\left(1.8-2 \mathrm{~g} \mathrm{~cm}^{-3}\right)$ and has been investigated can help activation of bone cells especially with the addition of calcium [7].

$\mathrm{Mg}$ implant has very high corrosion rate around $\pm 10-200 \mathrm{~mm} /$ year in $3,5 \% \mathrm{NaCl}$ which limit their application [8]. It caused difficulty of controlling degradation phenomena to achieve appropriate time for new tissue growth. Such condition made iron is considered to be an alternative candidate for implant material. Based on the invivo test result, iron implant showed a good tendency of iron-based material for the application of degradable implant materials. It used pure iron for stents and did not show a toxicity issue [9]. However, the degradation rate of pure iron is slow. To increase its degradation rate, Hermawan et al. developed a Fe-35wt\% Mn alloy with powder metallurgy process which showed an increase in degradation rate [3].

Currently, one focus of development iron-based implant metal finds a manufacturing process that could make a precise size. Currently, the typical method to produce implant used powder metallurgy $[3,10]$ and casting process [11]. Powder metallurgy process offers its ability to make a precision process for small size product as well as the presence of unintentionally formed porosity. Porosity is useful for increasing the ability of cells to attach to the implant substrate [12].

It has been stated that porosity will be beneficial in the process manufacturing of bone implants. Reza Alavi et al. (2017) has shown that there is no significant change in mechanical properties from foam material after the immersion process in Hanks solution [13]. One of the most promising fabrication methods for creating porous materials is the space holder method. This method utilizes ceramic or polymer to be sintered, and it will produce porosity in the desired shape. Bram et al. have succeeded produce porous materials using carbamide, as a raw material space holder (foam agent) of titanium and stainless steel [13]. Gulsoy and German succeed to produce 17-5PH stainless steel metal foam using carbamide. They found the porosity that resulted from the process is related with the number of carbamides in the alloy [14]. Bekoz, and E. Oktay (2012) successfully made a spherical foamed structure in $\mathrm{Fe}-1.5 \mathrm{Mo} \%$ materials using carbamide [15]. The compressive stress increased significantly compared with the irregular porosity.

This study aimed to find out the possibility of carbamide application for space holder (foaming agent) in Fe-Mn-C metal foam. Even though many research has been published about carbamide as a space holder, however, there is still limited study about the application of carbamide in IronManganese alloy. The manganese vapor is challenging problems in Fe-Mn-C metal foam development because of its ability to affect the decomposition process of the space holder.

The potential of carbamide as a space holder in biomaterial applications is promising because carbamide does not have a harmful raw element that might be present as a byproduct. Carbamide is composed of Nitrogen (N) and Hydrogen (H). So, the properties of material toxicity are expected to be unaffected by carbamide

\subsection{METHODOLOGY}

\subsection{Materials Fabrication}

The raw material for Fe-Mn-C alloy is iron (Fe), manganese $(\mathrm{Mn})$, carbon (C) powders with purity $99.9 \%$ and the particle size is about $<72 \mu \mathrm{m}$. The carbamide was $1 \mathrm{~mm}$. It was sieved to get the desired size of powder and weighed to get the target of the composition. Target composition of this research is $5 \%$ Carbamide and $10 \%$ Carbamide. This composition was chosen to get an ideal bonding between particle during the sintering. The low density of carbamide and size of the carbamide make the sample contain more carbamide in the volume perspective. Hence, higher \%wt of carbamide will cause metallic particle harder to bind each other because the sample will be covered by carbamide. Before the mixing process, all of the powder treated with $0.75 \mathrm{ml}$ ethanol to prevent segregation of metal powders and carbamide.

The mixing process was done by using rotary mixing for 30 minutes to get better distribution of each powder. It was compacted with a pressure of 2 tons for 15 minutes under isostatic pressure to get the green product. This green product was sintered to get the final product. There are two routes of the sintering process. Route $(A)$ is one stage sintering at temperature $200{ }^{\circ} \mathrm{C}$ to find out the effect of sintering in the decomposition of carbamide. Route (B) is a two-stage process in tube furnace using argon atmosphere. The first stage was carried out at $250^{\circ} \mathrm{C}$ for 2.5 hours to decompose the carbamide then the second stage was carried out at $1100^{\circ} \mathrm{C}$ for 1.5 hours to form bonds between the powders. Figure 1 showed schematics of the research process

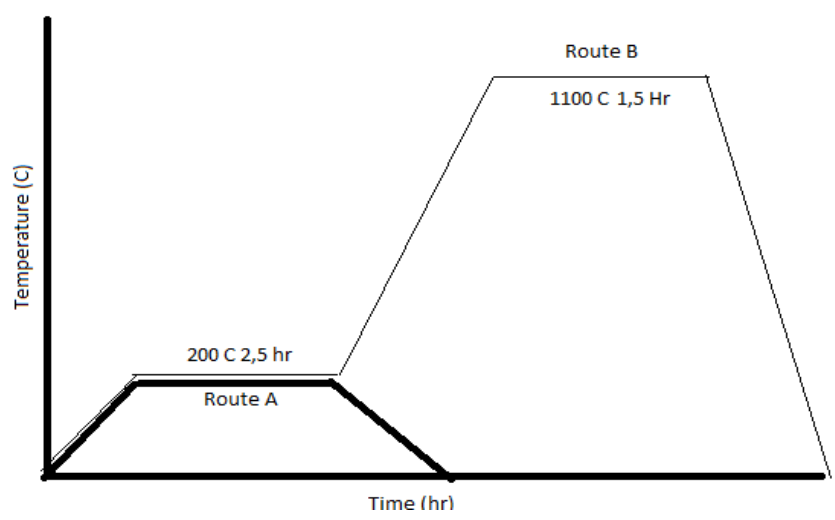

Figure 1 Processing route of the study 


\subsection{Characterization}

Sintered products were characterized by several aspects such as density, porosity, phase analysis, and microstructure. Each of the characterization specimens was cut using a low-speed diamond saw to minimize the effect of cutting in the microstructure result

\subsubsection{Bulk Density and Porosity}

Bulk Density testing was performed using the Archimedes principle by ASTM A378-88 standard. The principle of density testing is done by the ratio of mass in the air to the mass of the sample in the oil. The use of oil is selected to avoid selective leaching of excess carbamide or metals. Calculation of density is shown in equation 1

parchimedes $=\frac{M \text { sample }}{M \text { oil }} x$ oil

While to calculate the porosity, the first step calculates the theoretical density as shown in equation 2

$$
\begin{aligned}
& \text { pteoritical }=(\mathrm{p} F e x \% m F e)+(\mathrm{p} M n x \% m M n)+ \\
& (\mathrm{p} C x \% m C)+(\mathrm{p} C \text { Corbomide } x \% m \text { Carbomide })
\end{aligned}
$$

The theoretical density than used for porosity calculation in equation 3

$\%$ Porosity $=\frac{\text { p teoritical }- \text { parchimedes }}{p \text { teoritical }} \times 100 \%$

\subsubsection{Microstructure}

Olympus Optical Microscope performs the observation in order to see the dispersion of the material porosity with several magnifications. The specimens were etched using Nital 3\% that immersed in 10 seconds. After the etching process, the specimen was continued to immersed in ethanol to remove excess of Nital in porosity. Due to porosity issue in the materials, the drying was conducted in a low-temperature oven for fast drying process for 5 minutes to remove the excess of ethanol

\subsubsection{X-ray Diffraction Analysis}

X-ray Diffraction (XRD) analysis is performed using Cu Ka radiation with wavelength $1.541 \mathrm{~A}$. The scanning rate is $0.02^{\circ} / \mathrm{second}$. It was used to analyzed the Ferrite, Austenite and associated phase in the materials. A specimen of the XRD analysis was cut with diameter $2 \mathrm{~cm}$.

\subsection{RESULTS AND DISCUSSION}

\subsection{Bulk Density and Porosity}

The initial mass of the $5 \%$ carbamide sample was $10.50 \mathrm{~g}$, and $10 \%$ carbamide sample was $9.78 \mathrm{~g}$. After the sinter, the weight reduced to $9.76 \mathrm{~g}$ and $11.2 \mathrm{~g}$ respectively. So, the weight loss is about $7 \%$ and $13 \%$ for $5 \%$ and $10 \%$ carbamide sintered product. Based on these result, it showed that the carbamide is entirely decomposed in the sintering product of route A $\left(1100^{\circ} \mathrm{C}\right)$. However, there is a possibility of powder lost due to the sintering process. Effect of sintering on mass loss was showed in Figure 2. As shown in Figure 2, If we assume that the carbamide is removed entirely after sintering, the powder lost is about $2 \%$ and $3 \%$ wt. The possible explanation is caused by the manganese vaporization during sintering. Salak et (2012) finds the vaporization of manganese powder al $[16,17]$.

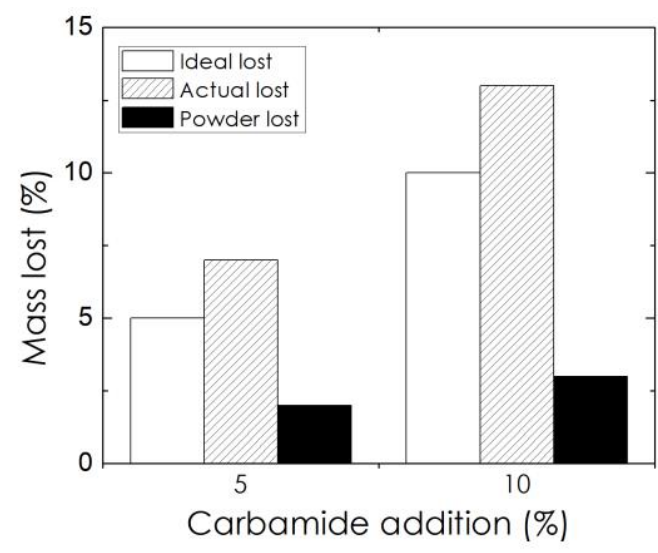

Figure 2 Mass loss after sintering at $1100 \mathrm{C}$

Density of the sample were decreased from 4.07 $\mathrm{g} / \mathrm{cm}^{3}$ (5\% Carbamide) to $3.73 \mathrm{~g} \mathrm{/} \mathrm{cm}^{3}$ (10\% Carbamide). The addition of $5 \%$ and $10 \%$ carbamide increased the percentage of metals porosity about $47 \%$ to $52 \%$ respectively as showed in table 1 . If compared with previous studies result which is without the addition of a foaming agent, the density is about of $5.84 \mathrm{~g} / \mathrm{cm}^{3}$ and porosity about $24.1 \% .^{18}$ Furthermore, if we compared the result with the potassium carbonate result $\left(3.62 \mathrm{gr} / \mathrm{cm}^{3}\right.$ at $10 \mathrm{wt} \%$ $\mathrm{K}_{2} \mathrm{CO}_{3}$ ), carbamide achieved similar density result. Therefore, it can be concluded that carbamide can work as a foaming agent. It will decompose into ammonia gas and iso-cyanuric acid, then it leaving the sample and form a porosity. Decomposition of carbamide is shown in equation 4. This result conforms with Davies (1983) et al. claims. Davies et al. stated the loose powder sintering usually achieve porosities about 40-60\%. ${ }^{19}$

$\mathrm{CO}\left(\mathrm{NH}_{2}\right)_{2} \stackrel{\text { heat }}{\longrightarrow} \mathrm{NH} 3(\mathrm{~g})+\mathrm{HNCO}(\mathrm{g})$ 
Table 1 Density and Porosity Result and Comparison with potassium carbonate

\begin{tabular}{|c|c|c|c|}
\hline \multirow[t]{2}{*}{ Properties } & \multicolumn{3}{|c|}{ \% Foaming Agent } \\
\hline & O['] & 5 & 10 \\
\hline Density of $\mathrm{K}_{2} \mathrm{CO}_{3}(\mathrm{gr} / \mathrm{cm} 3)\left[{ }^{18}\right]$ & 5.8 & 4.08 & 3.62 \\
\hline $\begin{array}{l}\text { Density of Carbamide } \\
\text { (gr/cm3) }\end{array}$ & 5.8 & 4.07 & 3.7 \\
\hline Porosity of $\mathrm{K}_{2} \mathrm{CO}_{3}\left[{ }^{18}\right](\%)$ & 24 & 47 & 52 \\
\hline Porosity of Carbamide (\%) & 24 & 47 & 53 \\
\hline
\end{tabular}

Porosity from route $\mathrm{A}\left(250^{\circ} \mathrm{C}\right)$ is higher than Route $B\left(1100^{\circ} \mathrm{C}\right)$ as shown in Figure 3 . The result shows most carbamide has been decomposed at that temperature. However, this porosity decreases after sintering at temperature of $1100{ }^{\circ} \mathrm{C}$, this phenomenon due to the densification process of the powder that closed the porosity that formed during the densification process.

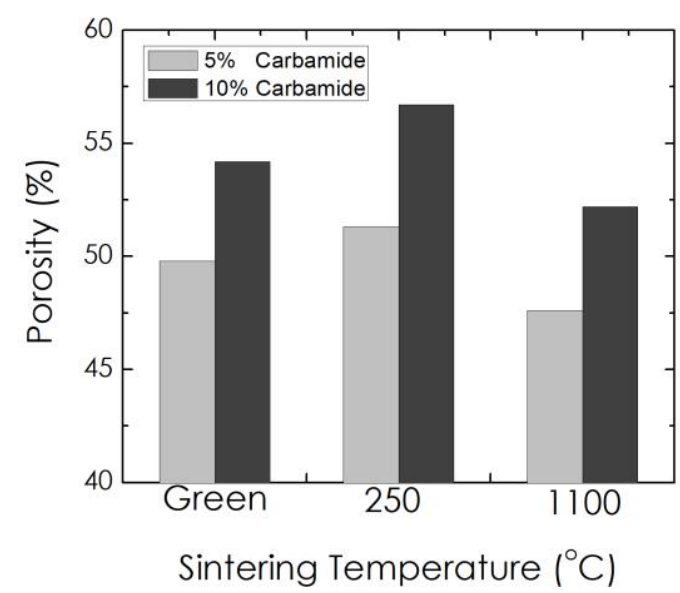

Figure 3 Porosity comparison between $250^{\circ} \mathrm{C}$ and $1100^{\circ} \mathrm{C}$ sintering product

Figure 4 showed the visual condition of metal after the sintering process in $1100^{\circ} \mathrm{C}$. The porosity morphology is spherical and identical with the carbamide size. If we compare with the previous study, the shape of the carbamide is more uniform than the result of $\mathrm{K}_{2} \mathrm{CO}_{3}$.
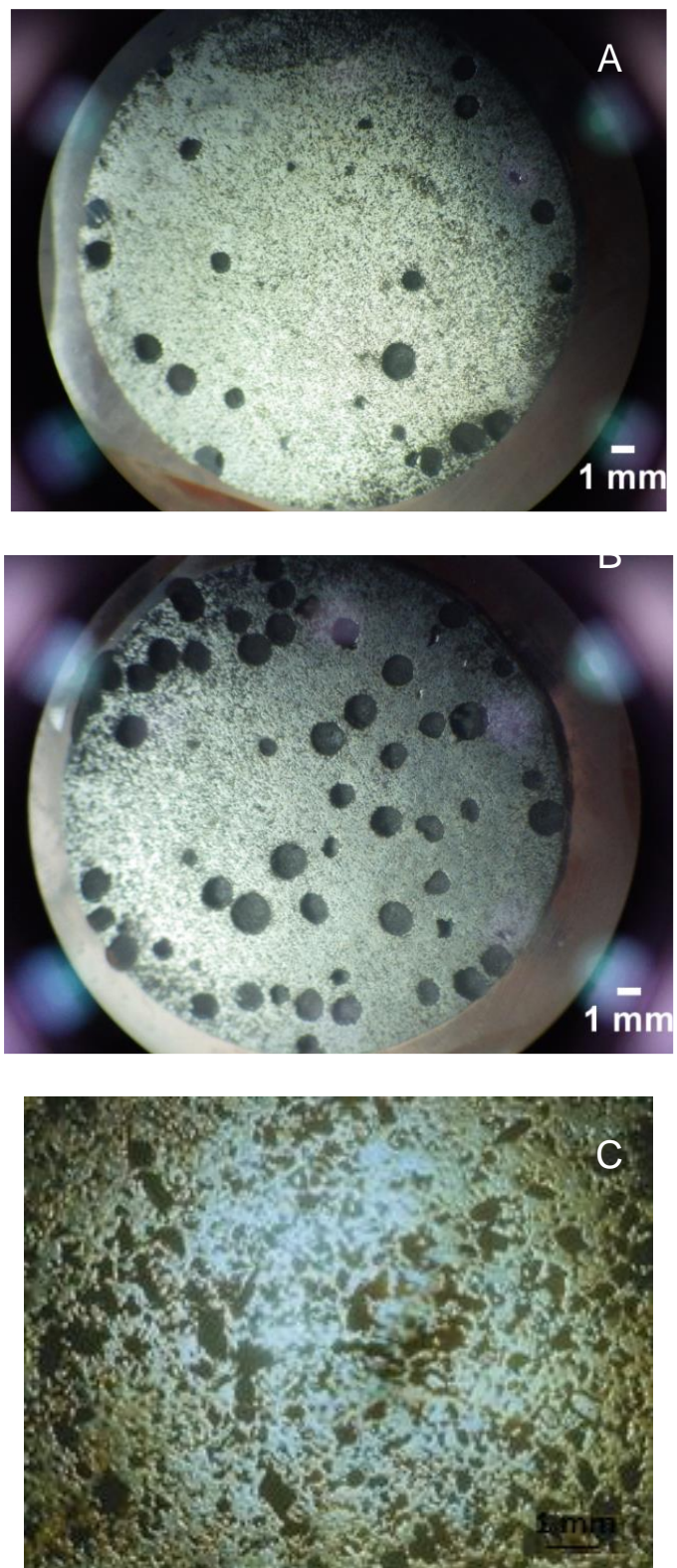

Figure 4 Comparison visual morphology of (A) carbamide $5 \%$, (B) Carbamide $10 \%$, and (C) $\mathrm{K} 2 \mathrm{CO} 3$

The diameters generated from the porosities are in the range of $1-1.3 \mathrm{~mm}$ which is similar to the carbamide size as shown in Figure 6. This condition showed the densification process during sintering did not affect the porosity. 


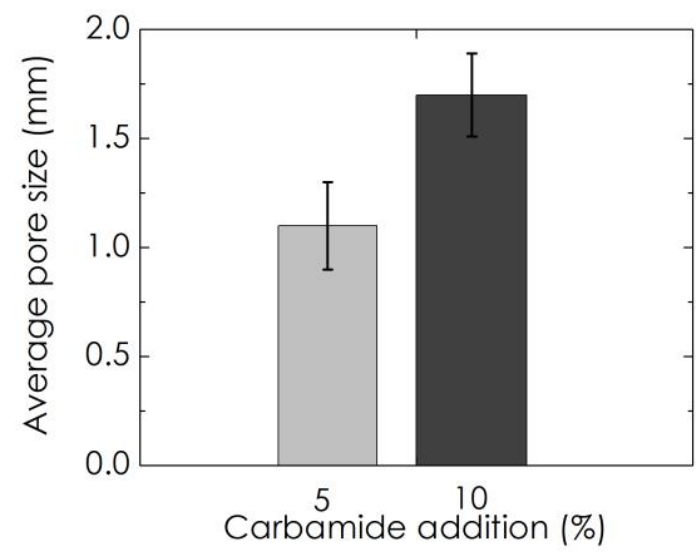

Figure 5 Average size of porosity from different carbamide addition samples, sintered at $1100^{\circ} \mathrm{C}$

However, the distribution of the porosity in carbamide product is not as good as $\mathrm{K} 2 \mathrm{CO} 3$. Our study had a separate porosity each other. This problem is caused by a low number of carbamide that added into the sample. However, a higher number of carbamide is unsuccessfully used in the sample due to the low-density issue. Hence, the carbamide size should be reduced to allow more carbamide addition in the sample.

Niu Wenjuan et al. used a smaller size of carbamide (200-600 $\mathrm{mm}$ ) and achieved $75 \%$ porosity. This study had a porosity size range $900-1100 \mu \mathrm{m}$ while Niu Wenjuan had 300- $500 \mu \mathrm{m} .{ }^{20}$ Table 2 showed the carbamide can hold the compression pressure and resulted in consistent pore size.

Table 2 Application of Carbamide as Space Holder in several alloy

\begin{tabular}{lll}
\hline Materials & $\begin{array}{l}\text { Carbamide } \\
\text { size }(\boldsymbol{\mu m})\end{array}$ & Pore size $(\boldsymbol{\mu m})$ \\
\hline Fe-Mn-C & $800-1100$ & $900-1100$ \\
\hline Titanium $^{20}$ & $200-600$ & $300-500$ \\
\hline Ti-6Al-4V $^{21}$ & $100-600$ & 400 \\
\hline Stainless steel $^{22}$ & $2000-2400$ & $1800-2300$ \\
\hline
\end{tabular}

\subsection{Phase Formation}

The XRD test was performed to prove the phase formed after the $1100^{\circ} \mathrm{C}$ sintering process. Figure 7 shows the phase formed on the $5 \%$ and $10 \%$ were of Austenite ( $\mathrm{Y}$ ), Ferrite (a), and manganese oxide $\left(\mathrm{MnO}_{2}\right) . \mathrm{MnO}_{2}$ showed that some of the manganese reacts with oxygen and does not diffuse into the Fe matrix. This manganese oxide phase is formed because the manganese evaporated form $\mathrm{Mn}$ vapor at temperature $400^{\circ} \mathrm{C}-1200^{\circ} \mathrm{C}$. This manganese vapor diffused into the iron matrix by the solid-gas process. [15].
As an effect of Manganese alloying, Ferrite transformed into Austenite. Manganese is well known an Austenite phase stabilizer which could make an Austenite phase stable at lower temperature. This phase is desirable in the fabrication of $\mathrm{Fe}-\mathrm{Mn}-\mathrm{C}$ biomaterials because it is not magnetic, so it does not interfere with examination using MRI. Hermawan et al. showed the magnetic susceptibility of Fe-35Mn is about $\sim 1.8 \times 10^{-7} \mathrm{~m}^{3} / \mathrm{kg}$ which considered as nonmagnetic materials [23].

Moreover, this study also found that ammonia gas, as a product of carbamide decomposition, did not interfere with the reaction between manganese and iron during sintering. While the fabrication of implant will develop the ammonia gas, this gas will be released during the fabrication. The remaining Nitrogen and Hydrogen bind with Fe and Mn make a nitride or hydride. Figure 6 also showed no remnant of carbamide decomposition product that still found after the sintering process. No phase caused by carbamide decomposition process

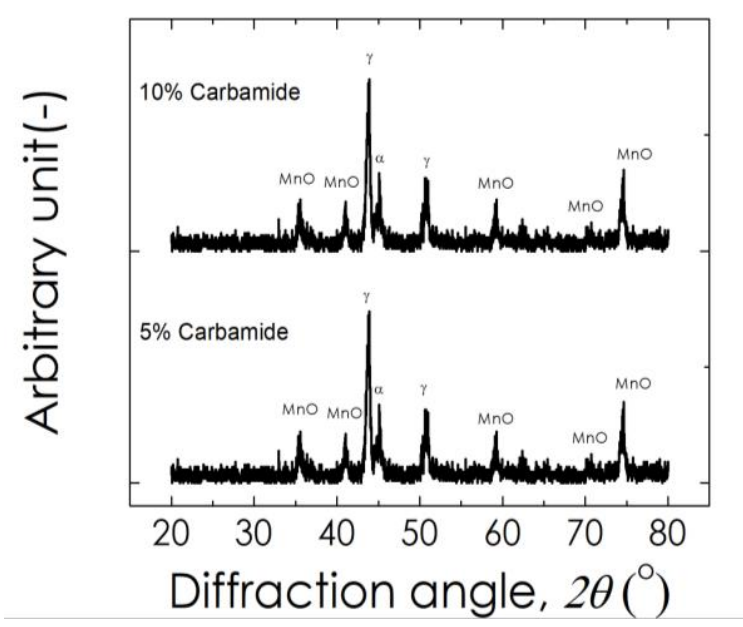

Figure 6 XRD patterns of the samples with 5 and $10 \%$ carbamide addition after sintering at $1100^{\circ} \mathrm{C}$

\subsection{Microstructure}

The microstructure of the sintered product showed Austenite and Ferrite phase. Twinning was found in the Austenite phase. Many micro porosities still found around the Ferrite and Austenite phase. This porosity is not a product of carbamide degradation. It is a typical product of the powder metallurgy process. During densification periods, there are several areas which did not affect growth nor made a necking between the grains. That area will produce a microporosity in the samples. The Ferrite phase is shown with the white phase that formed at the center of the iron powder. This phase still exists because of the inability of manganese to penetrate faster into the center of the iron powder [24]. The volume diffusion of $\mathrm{Mn}$ atom in Austenite is 1.60.10-10 $\mathrm{cm}^{2} \cdot \mathrm{s}^{-1}$ at $1250^{\circ} \mathrm{C}[25]$. 


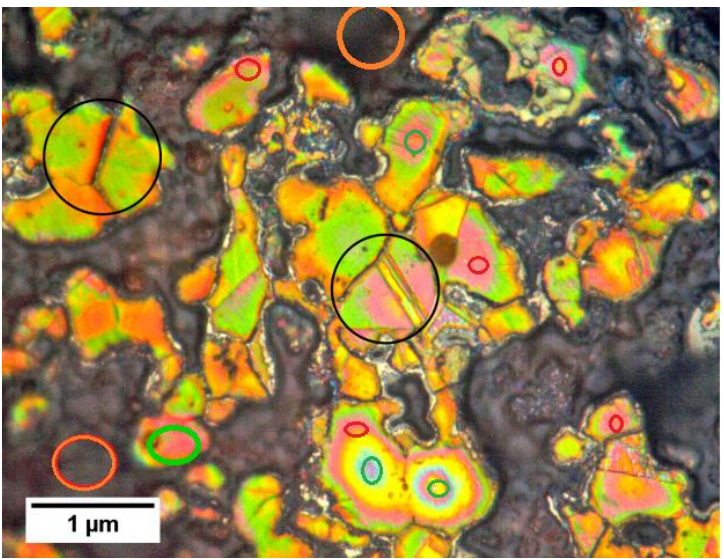

(a)

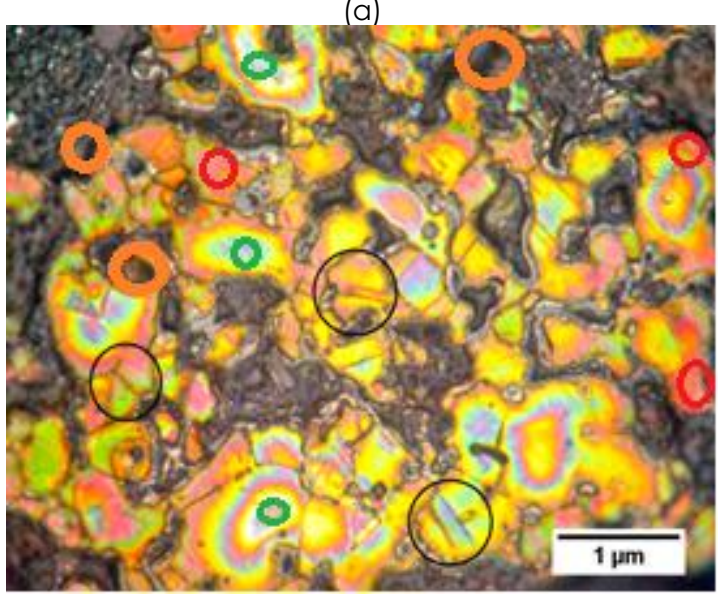

(b)

Figure 7 (a) 5\% Carbamide and (b) 10\% Carbamide showed twinning austenite (black), ferrite (green), pore (orange) and $\mathrm{MnO}_{2}$ (red)

\subsection{CONCLUSION}

Carbamide is a potential candidate to be used as space filling material to produce foam structure. It can withstand the pressure and do not deform during compactions. It also can decompose at a temperature below $1100{ }^{\circ} \mathrm{C}$. The size and morphology of the porous were similar with the carbamide. The decomposition gas product also did not interfere with the Austenite phase formation. However, a higher percentage addition of carbamide should be tried to give an open pore porosity

\section{Acknowledgment}

The author would like to say thank you for the Ministry of Research, Technology and Higher Education of Indonesia for the grant BOPTN 2014.

\section{References}

[1] W. Arbuthnot Lane, M. S. 1895. Some Remarks on the Treatment of Fractures. Treatment Fract. 1892-1894.

[2] Hryniewicz, T., Rokicki, R. \& Rokosz, K. 2008. Surface Characterization of AISI 316L Biomaterials Obtained by Electropolishing In a Magnetic Field. Surf. Coatings Technol. 202: 1668-1673

[3] Hermawan, H., Purnama, A., Dube, D., Couet, J. \& Mantovani, D. 2010. Fe-Mn Alloys for Metallic Biodegradable Stents: Degradation and Cell Viability Studies. Acta Biomater. 6: 1852-1860.

[4] Schinhammer, M., Hänzi, A. C., Löffler, J. F. \& Uggowitzer, P. J. 2010. Design Strategy for Biodegradable Fe-Based Alloys for Medical Applications. Acta Biomater. 6: 17051713.

[5] Polmear, I. J. 1999. ASM Specialty Handbook. ed. M. M. Avedesian, H. B. 12-25.

[6] Jahnen-Dechent, W. \& Ketteler, M. 2012. Magnesium Basics. Clin. Kidney J. 5: i3-il 4.

[7] Witte, F. et al. 2005. In Vivo Corrosion of Four Magnesium Alloys and the Associated Bone Response. Biomaterials. 26: 3557-3563.

[8] Li, L., Gao, J. \& Wang, Y. 2004. Evaluation of Cyto-toxicity and Corrosion Behavior of Alkali-Heat-Treated Magnesium in Simulated Body Fluid. Surf. Coatings Technol. 185: 92-98.

[9] Moravej, M., Purnama, A., Fiset, M., Couet, J. \& Mantovani, D. 2010. Electroformed Pure Iron as a New Biomaterial for Degradable Stents: In Vitro Degradation and Preliminary Cell Viability Studies. Acta Biomater. 6: 1843-1851.

[10] Harjanto, S. et al. 2013. Properties of Fe-Mn-C Alloy as Degradable Biomaterials Candidate for Coronary Stent. Adv. Mater. Res. 789: 210-214

[11] Liu, B. \& Zheng, Y. F. 2011. Effects of Alloying Elements (Mn, Co, Al, W, Sn, B, C and S) on Biodegradability and In Vitro Biocompatibility of Pure Iron. Acta Biomater. 7: 1407-1420.

[12] Khan, Y., Yaszemski, M. J., Mikos, A. G., L. C. 2008. Tissue Engineering of Bone: Material and Matrix Considerations. J Bone Jt. Surg Am. 90.

[13] Alavi, R., Trenggono, A., Champagne, S. \& Hermawan, H. (2017). Investigation on Mechanical Behavior of Biodegradable Iron Foams under Different Compression Test Conditions. Metals (Basel). 7: 202.

[14] Gülsoy, H. Ö. \& German, R. M. 2008. Sintered Foams from Precipitation Hardened Stainless Steel Powder. Powder Metall. 51: 350-353.

[15] Bekoz, N. \& Oktay, E. 2012. Effects of Carbamide Shape and Content on Processing and Properties of Steel Foams. J. Mater. Process. Technol. 212: 2109-2116.

[16] Andrej Šalak, M. S. 2012. Manganese in Powder Metallurgy Steels. Springer.

[17] Hryha, Eduard, and E. D. 2011. Application of Thermodynamics to Biological and Materials Science. InTech.

[18] Pratesa, Y., Harjanto, S., Larasati, A., Suharno, B. \& Ariati, M. 2018. Degradable and Porous Fe-Mn-C Alloy for Biomaterials Candidate. AIP Conf. Proc. 1933: 20007.

[19] Davies, G. J. \& Zhen, S. 1983. Metallic Foams: Their Production, Properties and Applications. J. Mater. Sci. 18: 1899-1911.

[20] Niu, W., Bai, C., Qiu, G. \& Wang, Q. 2009. Processing and Properties of Porous Titanium Using Space Holder Technique. Mater. Sci. Eng. A. 506: 148-151.

[21] Kotan, G. \& Bor, A. \$. 2007. Production and Characterization of High Porosity Ti-6Al-4V Foam by Space Holder Technique in Powder Metallurgy. Turkish J. Eng. Environ. Sci. 31: 149-156.

[22] Mirzaei, M. \& Paydar, M. H. 2017. A Novel Process for Manufacturing Porous 316 ? ? L Stainless Steel with Uniform Pore Distribution. Mater. Des. 121: 442-449.

[23] Hermawan, H., Dubé, D. \& Mantovani, D. 2009. Degradable Metallic Biomaterials: Design and 
Development of Fe-Mn Alloys for Stents. J. Biomed. Mater. Res. Part A. 93A: 1-11.

[24] Šalak, A., Selecká, M., \& Bureš, R. 2001. Manganese in Ferrous Powder Metallurgy. Powder Metallurgy Progress,
1(1): 41-58.

[25] Lide, D. R. (Ed.). 1987. Handbook of Chemistry and Physics. CRC Press. 